\title{
新しく開発した偽鍼とその信頼性
}

\author{
Jongbae Park (朴鍾培) 1) Adrian White ${ }^{1)} \quad$ Hyejung Lee（李惠貞） ${ }^{2)}$ \\ 山下 仁 ${ }^{1,3)}$ Edzard Ernst ${ }^{1)}$ \\ 1）エクセター大学大学院コンプレメンタリー医学研究室 \\ 2) 慶熙大学東西医学大学院 \\ 3）筑波技術短期大学附属診療所
}

\section{Credibility of a Newly Developed Sham Needle}

\author{
Jongbae Park ${ }^{1)} \quad$ Adrian White ${ }^{1)} \quad$ Hyejung Lee ${ }^{2)}$ \\ Hitoshi Yamashita ${ }^{1,3)}$ Edzard Ernst ${ }^{1)}$
}

1) Department of Complementary Medicine, School of Postgraduate Medicine and Health Sciences, University of Exeter

2) Postgraduate School of East \& West Medicine, Kyung Hee University

3) Tsukuba College of Technology Clinic

\begin{abstract}
Objective: To develop a sham needle, which is applicable to clinical trials on acupuncture and test its credibility.

Methods: The 'Park Sham Needle' unit was developed. The apparatus consists of a blunt needle, the shaft of which telescopes into the handle when tapped, so that while the needle appears to have been inserted, it does not actually pierce the skin, and a 'Park Tube' that is composed of a standard guide tube and an oversize guide tube with a plastic flange at one end which adheres to the skin with double-sided sticky tape. The needle is held in place by the Park Tube. In a credibility test, 56 subjects received our new sham needle on the left LI4 acupoint and were asked whether or not they felt the needle being inserted into the skin.
\end{abstract}

Results: Forty-six subjects (82\%) were convinced that they received real needle insertion.

Conclusion: Park Sham Needle seems to be applicable to randomised, subject-blinded, and controlled trials on acupuncture.

Key Words: Acupuncture, sham needle, placebo, clinical trial.

\section{I．緒言}

銊治療は東アジアにおいて様々な疾病に長く用 いられてきたが、近年は西洋においても使われ始 めてきている。しかしながら普及しているという ことが有効性を証明しているわけではない。銊の 治療効果を証明するためには適切なプラシーボ対
照群と比較しなければならない1)。プラシーボは、 あらゆる点で本物の介入（治療）と区別がつかず、 しかも治療効果や身体的反応を生じないものであ るべきである。しかしながら、銊においては皮膚 接触により生理学的反応が生じてしまう。このた め我々は「プラシーボ銊」というよりも「偽

(住所) Department of Complementary Medicine, School of Postgraduate Medicine and Health Sciences, University of Exeter 25 Victoria Park Road Exeter EX2 4NT, UK

Tel. +44 (0)1392 439035 E-mail: J.Park@exeter.ac.uk 
（sham）鍼」と呼ぶのが適当であると考えている。 理想的な偽銊の特徵としては、被験者（患者） が実際に銊を受けていると思い込むようなもので あろう。過去には、爪による压迫2)、プラスチッ クの鍼管3)、尖端を丸くした楊枝4)、尖端を粘着物 でカバーした鍼5)、あるいは表面的な銊刺激6)など が試されてきた。これらはいずれも充分とはいえ ない点があったが、Streitberger \& Kleinhenz ${ }^{7)}$ の開 発した偽鍼によって著しく進歩した。これは鍼先 の尖りをなくし、鍼体が鍼柄の中にはまり込むと いう仕組みになっている。刺鍼点の周囲に円形の リングを付着させ、その上を粘着性のカバーで覆 ってあり、ここにこの偽鍼を垂直に立てて刺銊動 作をするのである。彼らは既にこの偽鍼を用いて ランダム化比較試験を完遂している8)。しかし、こ の偽鍼については適用できる身体の部位や刺鍼手 技に制限があるという批判を受けている9)。この ような経緯を踏まえ、我々は支持用の銊管（Park Tube）を伴った「パク式偽鍼（Park Sham Needle）」 を開発し、その有用性を検証した。

\section{II. 方法}

1. 偽銊の開発（PhotoおよびFigure）
パク式偽銊は本物の鍼と外観では区別がつかな いが、鍼先が尖ってなく、下方に圧を加えると鍼 体が鍼柄にはまり込むようにした。銊柄はステン レス製で、中国鍼のように渦巻き状の形状をして おり、この内側にひっかかりながら鍼体がはまり 込むため、一定の抵抗を感じるようになっている。 鍼体の直径は $0.35 \mathrm{~mm}$ 、銊柄を含めた長さは $70 \mathrm{~mm}$ である。この鍼は大韓民国の鍼炎針メーカー「東 方銊尒製作所」に製作を依頼した。また偽鍼を刺 鍼部位で立てて保持するために、Park tubeを開発 した。これは両面テープで皮膚に張りつけるプラ スティックの管状の土台である。普通の銊管は Park tubeの内側に沿わせてセットする。偽銊も本 物の鍼の場合もこの操作は同じである。すなわち 内側から、鍼尒針（偽鍼または本物）、普通の銊 管、そしてPark tubeという構成である。

\section{2. 使用法}

刺銊動作は皮膚に対して垂直に行う。刺銊者は Park tubeを皮膚上の目的の位置に接着させて偽鍼 をセットする。次に本物の場合と同じように切皮 と刺入の動作をする。銊は刺入されているように 見えるが、実際には銊体は銊柄の側にはまり込ん でいる。雀豚術や旋撚術などの手技を行うことも
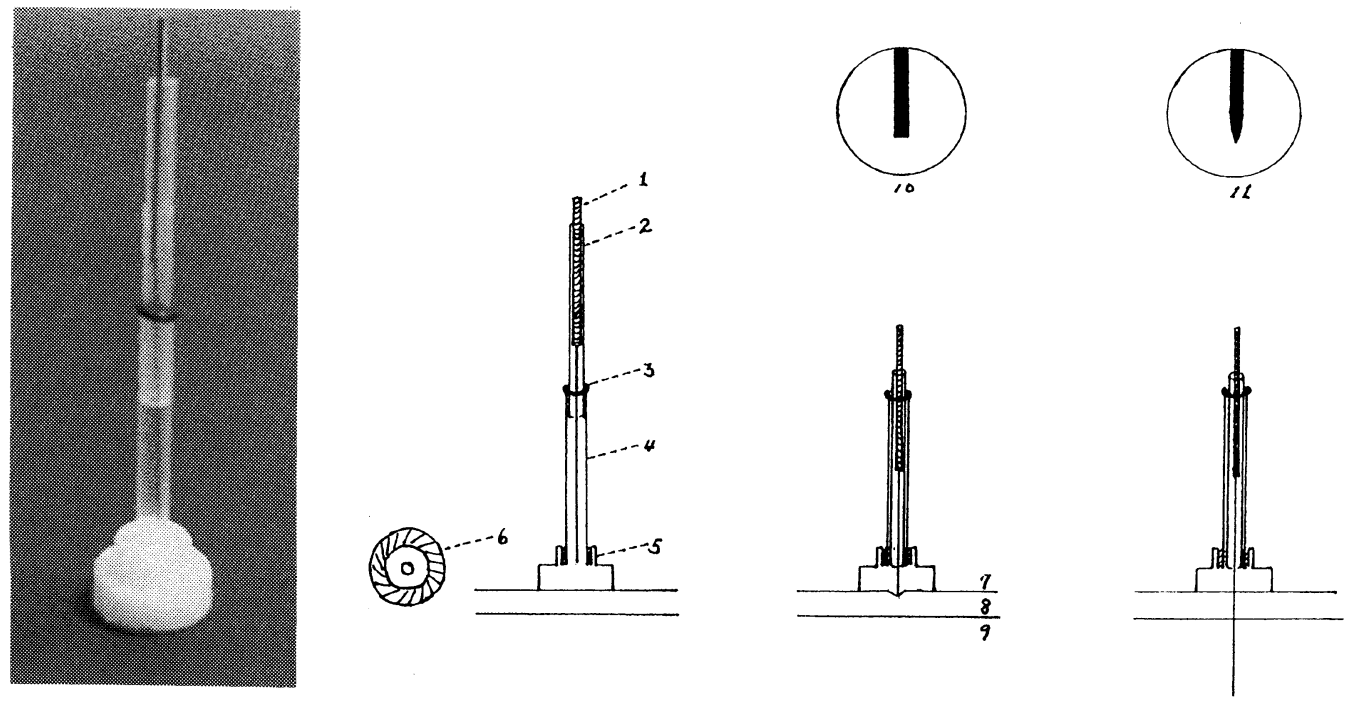

Figure. Park Sham Needle unit: 1. Needle handle, 2. Guide tube, 3. Guide O-Ring, 4. Park tube, 5. Flange, 6. Double sided tape, 7. Skin 8. Dermis, 9. Muscle, 10. Dull tip of sham needle, 11. Sharp tip of real needle 
できる。本物の銊を用いる場合も全く同じ過程で 行う。長さ $40 \mathrm{~mm}$ の銊体の銊を用いると、本物の 鍼なら $15 \mathrm{~mm}$ まで刺入することができる。銊と銊 管の長さを変えることにより刺入深度も変えるこ とができる。

\section{3. パク式偽鍼の信頼性の検証}

被験者として56名（男性6名、女性50名）の医 療スタッフ (Royal Devon \& Exeter Hospital, England）の協力を得た。年齢は18～57歳、平均 年齢は37.6歳（SD=11.3）、鍼治療を受けた経験の ある者は6名であった。被験者から見えないよう に箱で覆いをして、片方の合谷穴にパク式偽鍼で 刺銊動作をした。被験者には刺銊動作が本物の銊 によって行われているのか、偽銊なのかは知らせ なかった。刺鍼後に「この銊が皮虐を貫いて刺入 されているのを感じましたか」という質問を行い、 「はい」「いいえ」「わからない」から答えを選ん でもらった。

\section{III. 結果}

パク式偽鍼による刺鍼動作によって、56名の被 験者のうち、46名が質問に対して「はい」、6名が 「いいえ」、4名が「わからない」と答えた。銊の 受療経験のある6名の被験者の回答の内訳は、5名 が「はい」、1名が「いいえ」であった。

\section{N. 考察}

パク式偽鍼は、鍼体が銊柄の中にはまり込む点 ではStreitberger \& Kleinhenz ${ }^{7)}$ の開発した偽鍼と同 じである。しかし我々の偽銊は刺入動作中に持続 的に刺銊抵抗を感じることができる。また皮膚上 にPark tubeを貼付するだけなので、身体で適用で きる部位や刺銊手技の制限が少ない。

今回の検証の結果、パク式偽銊を使っているに もかかわらず、 $82 \%$ の被験者が実際に鍼が刺入さ れていると感じた。過去の報告7)によると、本物 の鍼によって実際に鍼が刺入されていると感じた 被験者は $90 \%$ \%っった。このことから、銊の臨床 試験における対照群に用いる鍼として、我々の偽 銊が適用可能であると判断している。ただし、鋭 い銊先はないものの皮虐接触刺激による生理学的 反応は生じる可能性がある。故にこの銊を用いた
臨床試験で可能なのは、刺入する銊の効果の検証 であり、切皮刺激や小児鍼の検証には適用できな い。しかし偽銊としては過去に用いられたいずれ の方式よりも進歩していると考えている。

偽銊を用いて鍼の臨床試験を行う際に得気感覚 を起こさせるかどうかについては様々な議論があ るであろう。Streitberger \& Kleinhenzらは、彼らの 偽鍼の有効性についての検証で、偽鍼を受けた被

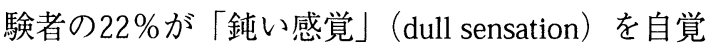
し、本物の鍼では $57 \%$ が自覚した報告しており、 彼らはこの「鈍い感覚」のことを得気と呼んでい る7)。しかしながらこれが我々の呼ぶ「得気」の ことを正確に示していたかどうかは明らかでない。 将来、もっと厳密に「鈍い感覚」と「得気」を区 別して調査するべきである。故に偽銊の開発と検 証の過程で、「得気」の適切な評価法の開発も同 時に必要となるであろう。

\section{V. 結論}

パク式偽鍼は、被験者をブラインド化した銊の ランダム化比較試験に適用可能であると考えられ た。

\section{謝辞}

製作した偽鍼を寄贈してくださった東方鍼尒製 作所に深謝いたします。

\section{参考文献}

1) Vincent C, Lewith G. Placebo controls for acupuncture studies. J R Soc Med 1995; 88:199202.

2 ) Junnila S. Acupuncture treatment for chronic pain. Acupunct Med 1983; 1:6-8.

3 ) Lao L, Bergman S, Anderson R, Langenberg P, Wong RH, Berman B. The effect of acupuncture on post-operative pain. Acupunct Med 1994;1317.

4) White AR, Eddleston C, Hardie R, Resch KL, Ernst E. A pilot study of acupuncture for tension headache, using a novel placebo. Acupunct Med 1996; 14:11-15.

5 ) Gallacchi G, Mueller W, Plattner GR, 
Schnorrenberger CC. Akupunktur- und Laserstrahlbehandlung beim Zervikal- und Lumbalsyndrom. Schweizerische medizinische Wochenschrift 1981; 111:1360-1366.

6 ) Hansen PE, Hansen JH. Acupuncture treatment of chronic tension headache - a controlled crossover trial. Cephalalgia 1985; 5:137-142.

7 ) Streitberger K, Kleinhenz J. Introducing a placebo needle into acupuncture research. Lancet 1998; 352:364-365.
8 ) Kleinhenz J, Streitberger K, Windeler J, bacher A, Mavridis G, Martin E. Randomised clinical trial comparing the effects of acupuncture and a newly designed placebo needle in rotator cuff tendinitis. Pain 1999; 83(2):235-241.

9 ) Kaptchuk T. Placebo needle for acupuncture. Lancet 1998; 352:992.

\section{要 旨}

我々は鍼の臨床試験に用いるために「パク式偽鍼（Park Sham Needle）」を開発した。この偽銊は銊先が 尖ってなく，切皮・刺入の動作の際に銊体が銊柄の中にはまり込むようになっている。このため実際には 銊先が皮膚を貫通していないのに，鍼が体内に挿入されているように見える。両面テープで皮膚に接着さ せた土台に固定された太い管（Park Tube）の中に，鍼管とともに偽銊をセットして用いる。

この偽銊の信頼性テストにおいて，56名の被験者のうち46名（82\%）が実際に銊が刺入されていると感 じた。このことからパク式偽銊は, 被験者ブラインドのランダム化比較試験に適用可能であると考えられ た。

キーワード : 鍼, 偽鍼, プラシーボ, 臨床試験 